Available online at GSC Online Press Directory

GSC Biological and Pharmaceutical Sciences

e-ISSN: 2581-3250, CODEN (USA): GBPSC2

Journal homepage: https://www.gsconlinepress.com/journals/gscbps

(RESEARCH ARTICLE)

\title{
Hematological evaluation of aqueous and methanolic leaf extracts of Thaumatococcus daniellii and Alchornea cordifolia in Wistar rats
} \author{
Nwanegwo Collins ${ }^{1}$ Ewa Ogbonnaya ${ }^{4, *}$ \\ ${ }^{1}$ Department of Human Physiology, Imo State University Owerri, Nigeria. \\ ${ }^{2}$ Department of Human Anatomy, Ahmadu Bello University Zaria, Nigeria \\ ${ }^{3}$ Department of Medical Biochemistry, Imo State University Owerri, Nigeria. \\ ${ }^{4}$ Department of Biochemistry, Ahmadu Bello University Zaria, Nigeria.
}

Amah Akuma Kalu ${ }^{1}$, Makena Wusa ${ }^{2}$, Ezekwe Ahamefula Sunday ${ }^{3}$, Ejiofor Dominic Chinedu ${ }^{1}$ and

Publication history: Received on 06 June 2019; revised on 25 July 2019; accepted on 30 July 2019

Article DOI: https://doi.org/10.30574/gscbps.2019.8.1.0102

\begin{abstract}
The study was conducted to evaluate the hematological indices of wistar rats administered with aqueous and methanolic leaf extracts of T. daniellii and A. cordifolia. The work was separated into two portions categorized as Study A and B. A total of twenty five (25) adult male wistar rats were used for both studies. Meanwhile, each study consisted of two distinct groups of five rats each. A common control (Group I) of five rats which was administered with $2 \mathrm{ml} / \mathrm{kg}$ distilled water orally was established for both studies. Groups II and III of Study A were administered with $200 \mathrm{mg} / \mathrm{kg}$ b.w aqueous and methanolic leaf extracts of $T$. daniellii orally respectively, while Groups II and III of Study B were administered with $200 \mathrm{mg} / \mathrm{kg}$ b.w aqueous and methanolic leaf extracts of $A$. cordifolia orally respectively. Animals were sacrificed after 14days of treatment and blood samples collected in EDTA containers were subjected to hematological analysis in accordance with standard procedures. Observations on Study A, showed that there was a significant reduction in the Hemoglobin concentration $(\mathrm{Hb})(13.7 \pm 0.01 \mathrm{~g} / \mathrm{l})$, Red Blood Cell (RBC) $(62.20 \pm 0.27 \times 106 / \mu \mathrm{L})$ and packed cell volume (PCV) $(38.75 \pm 0.02 \%)$ in group III of study A administered with $200 \mathrm{mg} / \mathrm{kg}$ b.w methanolic leaf extract of $T$. daniellii compared to the control $\mathrm{Hb}(17.13 \pm 0.01 \mathrm{~g} / \mathrm{dl})$, RBC $(69.83 \times 106 / \mu \mathrm{L})$ and PCV $(48.75 \pm 0.02 \%)$ respectively. However, the White Blood Cell was significantly high $(10.13 \pm 0.02 \times 103 / \mu \mathrm{L})$ in group III compared to the control $(7.13 \pm 0.02 \times 103 / \mu \mathrm{L})$. For Study B, administration of $200 \mathrm{mg} / \mathrm{kg}$ b.w aqueous and methanolic leaf extracts of $A$. cordifolia caused a significant reduction in $\mathrm{Hb}$ $(12.5 \pm 0.02 \mathrm{~g} / \mathrm{dl})$ and $(12.09 \pm 0.02)$, RBC $(61.92 \pm 0.06 \times 106 / \mu \mathrm{L})$ and $(61.42 \pm 0.31 \times 106 / \mu \mathrm{L})$ and PCV $(41.15 \pm 0.02 \%)$, $(42.33 \pm 0.15 \%)$ respectively compared to the control $\mathrm{Hb}(17.13 \pm 0.01 \mathrm{~g} / \mathrm{dl}), \mathrm{RBC}(69.83 \pm 0.01 \times 106 / \mu \mathrm{L})$ and PCV $(48.75 \pm 0.02 \%)$. On the contrary, WBC was significantly high in groups II and III $(9.54 \pm 0.02 \times 103 / \mu \mathrm{L})$ and $(9.07 \pm 0.06 \times 103 / \mu \mathrm{L})$ respectively compared to the control $(7.13 \pm 0.02 \times 103 / \mu \mathrm{L})$. In conclusion, preliminary drug discovery approach on T. daniellii leaf should prefer aqueous extraction so as to avoid components with possible anemia inducing capacity. However, the usage A. cordifolia extract as therapy should be complemented with an antianemic medication.
\end{abstract}

Keywords: Thaumatococcus daniellii; Alchornea cordifolia; Anemia

\section{Introduction}

The persistent rise in the dependence on plant derived therapies as a source of primary health care for the ever increasing population of the world has been acknowledged and reported by World Health Organization [1]. Alchornea cordifolia a perennial evergreen shrub measuring up to $4-8 \mathrm{~cm}$ high with erected shoots belongs to the family

\footnotetext{
${ }^{*}$ Corresponding author

E-mail address: ewahalfred@gmail.com
}

Copyright (C) 2019 Author(s) retain the copyright of this article. This article is published under the terms of the Creative Commons Attribution Liscense 4.0 
Euphorbiacea and commonly known as the Christmas Bush. It is mostly found in the marshy areas along the coastal regions of West Africa. A. cordifolia has been extensively used in tackling numerous human diseases in the African folk traditional medicine. These include diarrhea, bacterial as well as fungal infections etc [2].

Thaumatococcus daniellii also known as the sweet prayers plant or katemfe belonging to the family Marantaceae is a rhizomatous, perennial monocotyledonous herb which grows and thrives across the hot, humid, tropical rain forest and coastal zones of West Africa [3]. The height of a mature T. daniellii plant is about 3-4cm, with some large papery leaves of about $46 \mathrm{~cm}$ long bearing pale purple flowers as well as soft fruits containing a number of shiny black seeds. In addition, the leaf contains phytochemicals such as hydroxybenzoic acid and ellagic acid (Alizarine yellow).The use of $T$. daniellii in the African folk medicine is evident by the fact that its leaf sap is used as an anti-dote against venoms, stings and bites, while the leaf and root sap are used as sedative and has been instrumental in the management of mental conditions [3].

Hematological parameters are useful indices that can be relied upon to ascertain the toxic potential of plant extracts or herbal medicine in a living system [4]. They can be used to measure the influence of certain plant derived compounds on blood. Owing to their high sensitivity and reliability they can be considered the strength of ethical and rational research on disease diagnosis, prevention as well as treatment [5].

Although, scientific reports abound on the therapeutic potentials of T. dainiellii and A. cordifolia, information deficit on the hematological implications of their usage as therapies probably owing to the irrational belief that naturally sourced medications are safe necessitates the need for this important research to either consolidate or discard this wildly held belief of the local users.

\section{Material and methods}

\subsection{Collection and preliminary processing of plant material}

Leaves of $T$. daniellii and A. cordifolia were collected from a farmland within Uturu community in Isiukwuato Local Government Area of Abia State, Nigeria. The plants were subsequently taken to the herbarium unit of the Department of Forestry, Micheal Okpara University of Agriculture Umudike, Abia State Nigeria. The leaves were separately and thoroughly washed using clean water before being dried at room temperature. Dried leaves were ground separately to powder and sieved with a suitable wire mesh to obtain a fine powder.

\subsection{Extraction of plant materials}

Fifty gram (50 g) each of the powdered plant samples was placed separately in $500 \mathrm{ml}$ of methanol and water before being macerated at room temperature for four days. The mixture was agitated three times daily and was subsequently strained after which the damp solid material was, pressed and the combined liquids, filtered with the aid of a cheese cloth and Whatman No. 1 filter paper. The filtrate was extracted using soxhlet apparatus for 5-6hrs and subsequently concentrated under pressure to dryness in rotary evaporator at $25-30{ }^{\circ} \mathrm{C}$ [6]. The extracts were placed in the refrigerator and maintained at $5-10{ }^{\circ} \mathrm{C}$.

\subsection{Median lethal dose $50 \%$ test (LD50)}

Acute toxicity test was separately carried out on T. daniellii and A. cordifolia leaf extracts. Three groups of three rats each were administered with $10 \mathrm{mg}, 100 \mathrm{mg}$, and $1000 \mathrm{mg} / \mathrm{kg}$ of the various extracts orally before being observed for $24 \mathrm{hrs}$. In the absence of mortality in any of the groups, another three groups of one rat each were administered with 1600,2900 and $5000 \mathrm{mg} / \mathrm{kg}$ of plants extract orally after which the animals were observed for $48 \mathrm{hrs}$ [7].

\subsection{Animal}

Twenty five (25) adult male wistar rats (116-122 g) were purchased from the Animal House of the Department of Pharmacology, University of Nigeria Nsukka. The rats were housed in plastic cages in a well-ventilated room with a $12 / 12 \mathrm{hr}$ light/dark cycle and ambient temperature for three weeks to acclimatize.

\subsection{Experimental design}

The research was divided into two parts identified as Study A and B. A total of twenty five (25) wistar rats were used for both studies. Meanwhile, each study consisted of two distinct groups of five rats each. A common control (Group I) of five rats which was administered with $2 \mathrm{ml} / \mathrm{kg}$ distilled water orally was established for both studies thus; 


\section{Study A}

Group II - $200 \mathrm{mg} / \mathrm{kg}$ aqueous extract of T.d (p.o)

Group III - 200 mg/kg methanolic extract of T.d (p.o)

\section{Study B}

Group II - 200 mg/kg aqueous extract A.c (p.o)

GroupIII - 200 mg/kg methanolic extract A.c (p.o)

\subsection{Determination of haematological parameters}

Blood samples collected from experimental animals were introduced into appropriately labeled EDTA containers. Hematological evaluation was conducted on the samples in accordance with the method described by Malamo et al [8]. RBC and WBC were counted with the aid of the Neubaur's Chamber. Packed Cell Volume (PCV) was determined using Wintrobe hematocrit tube, while hemoglobin concentration (Hb) was determined using the Coulter Counter System (Beckman Coulter®, ThrmoFisher, UK).

\subsection{Statistical analysis}

Data generated from the study was analyzed with the aid of the Analysis of Variance (ANOVA) and were expressed as mean \pm standard error of mean (SEM) of three determinations. Differences in mean were compared using Duncan multiple test range, $\mathrm{P}<0.05$ was considered statistically significant.

\section{Results and discussion}

Table 1: Hematological indices of wistar rats administered with aqueous and methanol extracts of T. Daniellii

\begin{tabular}{ccccc}
\hline Group & Hb (g/d) & $\mathbf{R B C}(\times \mathbf{1 0} / \boldsymbol{\mu L})$ & $\mathbf{W B C}(\times \mathbf{1 0} / \boldsymbol{\mu L})$ & PVC\% \\
\hline Group I(ctrl) & $17.13 \pm 0.01^{\mathrm{a}}$ & $69.83 \pm 0.01^{\mathrm{a}}$ & $7.13 \pm 0.02^{\mathrm{a}}$ & $48.75 \pm 0.02^{\mathrm{a}}$ \\
Group II(200 mg/kg aq. T.D) & $17.02 \pm 0.01^{\mathrm{a}}$ & $68.64 \pm 0.49^{\mathrm{ab}}$ & $7.83 \pm 0.02^{\mathrm{a}}$ & $45.44 \pm 0.02^{\mathrm{ab}}$ \\
Group III (200 mg/kg met. T.D ) & $13.7 \pm 0.01^{\mathrm{b}}$ & $62.20 \pm 0.27^{\mathrm{c}}$ & $10.13 \pm 0.02^{\mathrm{b}}$ & $38.93 \pm 0.02^{\mathrm{c}}$ \\
\hline \multicolumn{2}{r}{ Values are mean \pm standard error of mean (SEM) from three determinations. Values with different superscripts in a column are significantly } \\
different (P<0.05)
\end{tabular}

Table 2: Hematological parameters of wistar rats administered with aqueous and methanol Extracts of $A$. cordifolia

\begin{tabular}{ccccc}
\hline Groups & Hb (g/dl) & RBC $\left(\times \mathbf{1 0}^{\mathbf{6}} / \boldsymbol{\mu L}\right)$ & $\mathbf{W B C}\left(\times \mathbf{1 0}^{\mathbf{3}} / \boldsymbol{\mu L}\right)$ & PCV\% \\
\hline Group I(ctrl) & $17.13 \pm 0.01 \mathrm{a}$ & $69.83 \pm 0.01^{\mathrm{a}}$ & $7.13 \pm 0.02^{\mathrm{a}}$ & $48.75 \pm 0.02^{\mathrm{a}}$ \\
Group IV(200 mg/kg aq. A.c) & $12.5 \pm 0.02 \mathrm{~b}$ & $61.92 \pm 0.56^{\mathrm{b}}$ & $9.54 \pm 0.02^{\mathrm{b}}$ & $41.15 \pm 0.02^{\mathrm{b}}$ \\
Group V (200 mg/kg met. Ac) & $12.19 \pm 0.02 \mathrm{~b}$ & $61.42 \pm 0.31^{\mathrm{b}}$ & $9.07 \pm 0.06^{\mathrm{b}}$ & $42.33 \pm 0.15^{\mathrm{b}}$ \\
\hline
\end{tabular}

Values are mean \pm standard deviation from three determinations. Values with different superscripts in a column are significantly different $(\mathrm{P}<0.05)$

Blood is an ideal indicator universally employed in the determination of an organism's health status [9]. It is said to be a mirror with which pathological conditions can be traced, identified and managed. Cellular components of blood are valuable tools in evaluating the toxic potentials of therapeutic compounds. Owing to these interesting qualities of blood, haematological parameters which beckon wholly on blood are essential in evaluating and establishing the body's functional status following exposure to toxicants [10].

Table 1 shows the hematological indices of wistar rats administered with aqueous and methanolic leaf extracts of $T$. daniellii. There was a significant decrease in the Hemoglobin concentration (Hb), Red Blood Cell (RBC) and Packed Cell Volume (PCV) in Group III administered with $200 \mathrm{mg} / \mathrm{kg}$ methanolic extract of $T$. daniellii compared to Group I administered with $2 \mathrm{ml} / \mathrm{kg}$ distilled water orally. However, there was no significant difference in the values obtained for Groups II and I administered with $200 \mathrm{mg} / \mathrm{kg}$ aqueous leaf extract of $T$. daniellii and $2 \mathrm{ml} / \mathrm{kg}$ distilled water orally 
respectively. Significant increase in White Blood Cell (WBC) was observed following the administration of $200 \mathrm{mg} / \mathrm{kg}$ methanolic leaf extract of $T$. daniellii compared to the control group.

Table 2 shows the hematological indices of wistar rats administered with aqueous and methanolic leaf extracts of $A$. cordifolia. A significant reduction in hemoglobin concentration (Hb), Red Blood Cell (RBC), White Blood Cell count (WBC) and Packed Cell Volume (PCV) was observed in Groups II and III administered with $200 \mathrm{mg} / \mathrm{kg}$ aqueous and methanolic leaf extracts of $A$. cordifolia respectively. The decrease in Hb, RBC and PCV observed following administration of the various leaf extracts could be as a result of the presence of some bioactive compounds with the capacity to suppress normal erythropoiesis promoting mechanisms and or deficiency of some factors required for the maturation of red blood cells [9]. Lysis of erythrocytes has been implicated in some instances [11].

The white blood cells in human, like every other higher animal respond to various sensors including infections and chemical irritants [12]. Thus, increase in the number of white blood cells is a normal reaction to exposure to toxicants [11]. The observable increase in the WBC (leukocytosis) may be as result of the excitation of the defense mechanism to counter the effects of the toxicants [13].

These results are consistent with the findings of Yaya and Ajay [9] which showed that taraxel and Apigenin bioactive compounds isolated from Jatropha gossypifolia belonging to the family Euphorbiacea to which A. cordifolia belongs could decrease blood parameters such as $\mathrm{Hb}, \mathrm{PCV}, \mathrm{RBC}$ and increased WBC.

\section{Conclusion}

In conclusion, diverse solvents are available for the isolation of bioactive compounds from varying plant parts. Accurate knowledge of their capacities is important in the preliminary drug discovery approach. From these studies, it can be deduced that drug discovery approach on T. daniellii leaf should preferably involve an aqueous medium. This is to avoid inclusion of potential anemia inducing compounds present in candidate plant. However, the usage of the aqueous leaf extract of $A$. cordifolia for therapeutic reasons should be complemented with an anti-anemic drug or preparations.

\section{Compliance with ethical standards}

\section{Acknowledgments}

We are grateful to the Department of Human Physiology Imo University State University for providing us with facilities to complete this work.

\section{Disclosure of conflict of interest}

We declare that no conflict of interest exist on this work.

\section{References}

[1] World Health Organisation. (2005). WHO Traditional Medicine Strategy. World Health Organization, Geneva.

[2] George NJ, Obot IB, Ikot AN, Akpan AE and Obi-Egbedi NO. (2010).phytochemical and antimicrobial properties of leaves of Alchorneacordifolia. European Journal of Chemistry, 7(3), 1071-1079.

[3] Onwueme IC, Onochie BE and Sofowora E. (1979). Cultivation of Thaumatococcus daniellii the sweetener. World Crops, 3, 106-111.

[4] Sunmonu TO and Oloyede OB. (2010). Performance and hematological indices in rats exposed to monocrotophos contamination. Human Experimental Toxicology, 29(10), 845- 850.

[5] Okonkwo JE, Iyadi KC and Effing CO. (2004). Effect of chronic administration of hematological parameters of rats. Nigerian Journal of Physiological Science, 19 (12), 10-13

[6] Phrompittayarat W, Putalun W, Tanaka H, Jetiyanon, K, Wittaya-areekul S and Ingkaninan K. (2007). Comparison of various extraction methods of Bacopa monnieri. Naresuan University Journal, 15(1), 29-34.

[7] Lorke D. (1983). New approach to practical acutetoxicity. Archive of Toxicology, 6(13), 54. 
[8] Malomo SO, Adebayo JO, Olorunniji FJ, Prohp TP, Mendie EA and Madusha A0. (2002). Modulatory effect of vitamin $\mathrm{E}$ on some haematological parameters in dihydroartemisin in treated rats. Tropical Journal of Health Science, 114-116.

[9] Jaya S and Ajay S. (2011). Effect of bioactive compounds extracted from euphorbious plants on hematological and biochemical parameters of Channa punctatus. Revista do Instituto de Medicina Tropical de São Paulo, 53(5), 259-263.

[10] Joshi PK., Bose M and Harish D. (2002). Haematological changes in the blood of Clarias battrachus exposed to mercuric chloride. Ecotoxicological Environmental Monitoring, 12, 119-122.

[11] Kori-Siakpere 0 and Ubogu EO. (2008). Sub-lethal hematological effects of zinc on the freshwater fih, Heteroclarias sp. (Osteichthyes: Clariidae). African Journal of Biotechnology, 7, 2068-73.

[12] Christensen GM, Faindt JT and Poeschi BA. (1978). Cells, proteins and certain physical-chemical properties of brook trout (Salvelinus fontinalis) blood. Journal of Fish Biology, 12, 51-60.

[13] Gabriel UU, Obomanu FG and Edori OS. (2009). Haematology, plasma enzymes and organ indices of Clariasgariepinus after intramuscular injection with aqueous leaves extracts of Lepidagathis alopecuroides. African Journal of Biochemical Research, 3, 312-6.

\section{How to cite this article}

Amah AK, Makena W, Ezekwe AS, Ejiofor DC and Nwanegwo C and Ewa O. (2019). Hematological evaluation of aqueous and methanolic leaf extracts of Thaumatococcus daniellii and Alchornea cordifolia in Wistar rats. GSC Biological and Pharmaceutical Sciences, 8(1), 123-127. 